\title{
AKTIVITAS ANTIOKSIDAN DAN ANTIBAKTERI EKSTRAK DAUN Jatropha gossypifolia $L$
}

\author{
Nia Sapitri Pangestu* ${ }^{\mathbf{1}}$, Nurhamidah ${ }^{2}$, Elvinawati $^{3}$ \\ Program Studi Pendidikan Kimia Fakultas Keguruan dan Ilmu Pendidikan Universitas Bengkulu \\ ${ }^{1,2,3}$ Program Studi Pendidikan Kimia, Jurusan PMIPA FKIP, Universitas Bengkulu \\ email : niapangestu87@gmail.com
}

\begin{abstract}
This study was conducted to determine the activity of Jatropha gossypifolia L (jarak merah's) leaf extract as an antioxidant and antibactery against acne causing bacteria (Propionibacterium acnes). To obtain an J. gossypifolia L jarak merah's leaf extract by maceration using 96\% ethanol, and then fractionated with n-hexane and ethyl acetate. Testing of antioxidant activity by DPPH method and antibactery activity test by the paper disc method. Antioxidant activity test has done for ethanol fraction, ethyl acetate fraction and n-hexane fraction, while testing for antibacterial activity performed on fractions active as antioxidant. The test results demonstrate the antioxidant activity of ethyl acetate fraction and the ethanol fraction as a fraction very strong with $\mathrm{IC}_{50}$ value of $22.33 \mathrm{ppm}$ for ethyl acetate fraction and $41.04 \mathrm{ppm}$ for ethanol fraction. Then the fraction of ethyl acetate and ethanol fraction antibactery activity test, the result is known that both factions have the ability to inhibit the growth of bacteria Propionibacterium acnes demonstrated by the inhibition zone is formed. In $1000 \mathrm{ppm}$ is formed diameter of the greatest inhibition zone that is equal to $6 \mathrm{~mm}$ for ethyl acetate fraction and $5 \mathrm{~mm}$ for ethanol fraction.
\end{abstract}

Keywords: Jatropha gossypifolia L., Propionibacterium acnes, Antioxidant, Antibacterial

\begin{abstract}
Abstrak
Penelitian ini dilakukan untuk mengetahui aktivitas ekstrak daun jarak merah (Jatropha gossypifolia L.) sebagai antioksidan dan antibakteri terhadap bakteri penyebab jerawat (Propionibacterium acnes). Pada uji aktivitas antioksidan dilakukan pada fraksi etanol, fraksi etil asetat dan fraksi n-heksana, sedangkan untuk pengujian aktivitas antibakteri dilakukan pada fraksi yang aktif sebagai antioksidan. Hasil uji aktivitas antioksidan menunjukkan fraksi etil asetat dan fraksi etanol sebagai fraksi yang sangat kuat dengan nilai $\mathrm{IC}_{50} 22,33$ ppm untuk fraksi etil asetat dan 41,04 ppm untuk fraksi etanol. Kemudian fraksi etil asetat dan fraksi etanol dilakukan uji aktivitas antibakteri, hasilnya diketahui bahwa kedua fraksi tersebut memiliki kemampuan untuk menghambat pertumbuhan bakteri Propionibacterium acnes terlihat dengan adanya zona hambat yang terbentuk. Pada konsentrasi 1000 ppm terbentuk diameter zona hambat yang paling besar yaitu sebesar $6 \mathrm{~mm}$ untuk fraksi etil asetat dan $5 \mathrm{~mm}$ untuk fraksi etanol.
\end{abstract}

Kata kunci : Jatropha gossypifolia L., Propionibacterium acnes, Antioksidan, Antibakteri

\section{PENDAHULUAN}

Jerawat merupakan salah satu masalah kulit yang sering dijumpai dan bersifat berulang dan memiliki prevalensi paling tinggi pada usia remaja, salah satunya akibat karena adanya aktivitas bakteri Propionibacterium acnes (P.acnes). Pengobatan jerawat antara lain adalah dengan menggunakan antibiotik seperti tetrasiklin, eritromisin, doksisiklin dan klindamisin [1], dengan efek samping dalam peng-gunaannya antara lain dapat menimbulkan iritasi serta munculnya resistensi bakteri. Oleh karena itu perlu dikembangkan obat jarawat yang berasal dari alam yang tidak menimbulkan efek samping jika dikon-sumsi secara tepat.[2]

Salah satu tanaman yang telah banyak dimanfaatkan sebagai obat adalah Jatropha gossypifolia $L$. (jarak merah) yang merupakan family dari Euphorbiaceae, yang dimanfaatkan untuk mengatasi susah buang air besar, radang anak telinga, pembengkakan, penyakit kulit, dan demam [3]. Pada penelitian yang telah dilakukan diketahui daun J. gossypifolia L. memiliki kandungan metabolit sekunder berupa minyak atsiri [4], yang terbukti memiliki aktivitas anti-bakteri terhadap tiga bakteri yaitu Escherichia coli, Enterococcus faecium dan Staphlococus aureus [5].

Senyawa-senyawa metabolit sekunder tanaman yang mempunyai aktivitas antibakteri juga umumnya dapat berfungsi sebagai antioksi dan antara lain termasuk dalam golongan senyawa fenol, flavonoid, terpenoid, saponin, dan alkaloid. [6,]. Antioksidan adalah suatu senyawa atau komponen kimia yang dalam kadar atau jumlah tertentu mampu menghambat atau memperlambat kerusakan akibat proses oksidasi, dan dibutuhkan tubuh untuk melindungi tubuh dari serangan radikal bebas [7]. Golongan senyawa flavonoid memiliki kemampuan sebagai antioksidan, dimana flavonoid memiliki kemampuan untuk mereduksi radikal bebas [8]. Antioksidan digolongkan menjadi dua jenis berdasarkan sumbernya, yaitu antioksidan sintetik dan antioksidan alami. Adanya kekhawatiran akan kemung- 
kinan efek samping dari antioksidan sintetik menjadikan antioksidan alami menjadi alternatif yang sangat dibutuhkan [9]. Tujuan penelitian ini adalah untuk menentukan besarnya aktivitas anti-oksidan dari ekstrak daun $J$. gossypifolia dan menge-tahui daya hambat dari fraksi daun terhadap partum-buhan bakteri P.acnes.

\section{METODE PENELITIAN}

Alat-alat yang diperlukan dalam penelitian ini adalah neraca analitik, corong pisah, statif dan ring, labu ukur, Erlenmeyer $250 \mathrm{~mL}$, pengaduk kaca, rotary evaporator, hot plate, pipet tetes, pipet ukur, pipet mikro, tabung reaksi, gelas beker $250 \mathrm{~mL}$, gelas ukur, blender, spektrofotometer UV-VIS, cawan petri, cawan porselin, jarum ose, pinset, lampu spritus, outoklaf, oven, inkubator, kertas saring Whatman no.1, penggaris milimeter, mikroskop, lemari pendingin, aluminium foil, Vortex, dan laminari air flow.

Bahan yang digunakan dalam penelitian ini ialah daun $J$. gossypifolia L., etanol teknis $96 \%$, n-heksana, etil asetat, aquades, $\mathrm{HgCl}_{2}, \mathrm{KI}$, Iodium, $\mathrm{HCl} 1 \mathrm{M}$, Bubuk $\mathrm{Mg}, \mathrm{FeCl}_{3} 1 \%, \mathrm{CH}_{3} \mathrm{COOH}$ glasial, $\mathrm{H}_{2} \mathrm{SO}_{4}$ pekat, methanol p.a, amonia, kloroform, DPPH, asam askorbat, nutrient agar, nutrient borth, bakteri P.acnes, antibiotik tetrasiklin.

\section{Prosedur Penelitian}

Sampel daun J.gossypifolia $L$ dibersihkan dan diiris, kemudian dikeringkan dengan cara dianginanginkan tanpa cahaya matahari langsung. Kemudian daun dihaluskan menggunakan belender, sehingga diperoleh sampel berupa serbuk.

Ekstraksi daun $J$. gossypifolia $L$ menggunakan metode maserasi dengan pelarut etanol $96 \%$. Fraksinasi dilakukan dengan pelarut n-heksana dan etil asetat.

Uji aktivitas antioksidan dilakukan dengan menggunakan metode 1,1-difenil-2-pikrilhidrazil (DPPH) terhadap fraksi n-heksana, etil asetat dan etanol dari daun J. gossypifolia $L$ dengan variasi konsentrasi untuk masing-masing larutan uji adalah 5, 15, 25 ,50, 75, 100, dan $125 \mathrm{ppm}$, dengan asam askorbat digunakan sebagai pembanding pada konsentrasi 1, 2, $5,10,15,20$, dan 25 ppm. Pengujian dilakukan dengan mengambil $1 \mathrm{~mL}$ dari masing-masing larutan uji dimasukkan ke dalam botol vial, lalu ditambahkan $1 \mathrm{~mL}$ DPPH 100 ppm, dan $2 \mathrm{~mL}$ metanol p.a kemudian diinkubasi selama 30 menit. Larutan ini kemudian diukur absorbansinya pada panjang gelombang $517 \mathrm{~nm}$. Besarnya konsentrasi ekstrak larutan uji untuk meredam 50\% aktivitas radikal bebas ditentukan dengan nilai $\mathrm{IC}_{50}$ yang dihitung dari persentase penghambatan serapan larutan ekstrak dengan menggunkan persamaan yang diperoleh dari kurva regresi linear.

Pengujian aktivitas antibakteri dilakukan dengan metode difusi cakram. Sebanyak $100 \mu \mathrm{L}$ suspensi bakteri dituang kedalam media NA steril yang telah diletakkan dalam cawan petri steril. Kemudian diratakan sampai memenuhi semua permukaan media. Lalu kertas cakram yang sudah steril ditetesi $10 \mu \mathrm{l}$ larutan uji dengan konsentrasi yang berbeda yaitu 62,5 , 125, 250 ,500 dan 1000 ppm didiamkan selama 15 menit agar larutan uji meresap ke dalam kertas cakram. Sebagai kontrol positif digunakan antibiotik tetrasiklin dengan konsentrasi 62,5 ppm dan kontrol negatif digunakan aquades. Kemudian kertas cakram tersebut diambil menggunakan pinset steril diletakkan di atas permukaan media yang telah diberi bakteri uji dan dibuat dua sisi. Kemudian semua media diinkubasi ke dalam inkubator. Inkubasi dilakukan pada suhu $37^{\circ} \mathrm{C}$ dengan posisi terbalik selama 24 jam. Setelah inkubasi dilakukan pengukuran diameter zona hambat.

\section{HASIL DAN PEMBAHASAN}

Pada penelitian ini digunakan sampel daun $J$. gossypifolia $L$ yang diambil dari Desa Lagan Bungin Kecamatan Talang Empat, Kabupaten Bengkulu Tengah. Setelah proses pegeringan dan penghalusan diperoleh dari \pm 2650 gram daun segar diperoleh \pm 625 gram serbuk daun $J$. gossypifolia $L$ kering, sehingga diperoleh kadar air pada daun jarak merah adalah sebesar $76,42 \%$.

Dari proses maserasi diperoleh $2625 \mathrm{~mL}$ ekstrak etanol cair yang setelah diuapkan menggunakan rotary evaporator diperoleh ekstrak kental etanol sebanyak 17,5 gram, yang berarti memiliki rendemen sebesar $4,38 \%$. Nilai \% rendemen menunjukkan seberapa besar jumlah kandungan metabolit sekunder yang terdapat pada sampel kering . Ekstrak kental etanol selanjutnya dipartisi dengan n-heksana sebanyak 6 kali sehingga diperoleh fraksi n-heksana dan fraksi etanol. Selanjutnya fraksi etanol dipartisi kembali dengan etil asetat sebanyak 5 kali sehingga diperoleh fraksi etil asetat dan fraksi etanol. Kemudian ketiga fraksi ini diuapkan pelarutnya hingga diperoleh fraksi berupa fraksi kentalnya, Hasil partisi diperoleh fraksi etanol sebesar 0,66 gram, fraksi etil asetat 0,76 gram, dan fraksi n-heksana 6,23 gram. Lalu masing-masing fraksi diuji aktivitas antioksidan dan fraksi yang aktif sebagai antioksidan dipilih untuk diuji aktivitas antibakterinya. Pengukuran potensi antioksidan dilakukan dengan berbagai konsentrasi sampel yakni $125,100,75,50,25,15$, dan 5 ppm, selanjutnya diukur serapannya dengan panjang gelombang $517 \mathrm{~nm}$. Sehingga diperoleh kurva regresi linier untuk masing masing fraksi sebagai berikut (Gambar 1,2,3 dan 4) : 


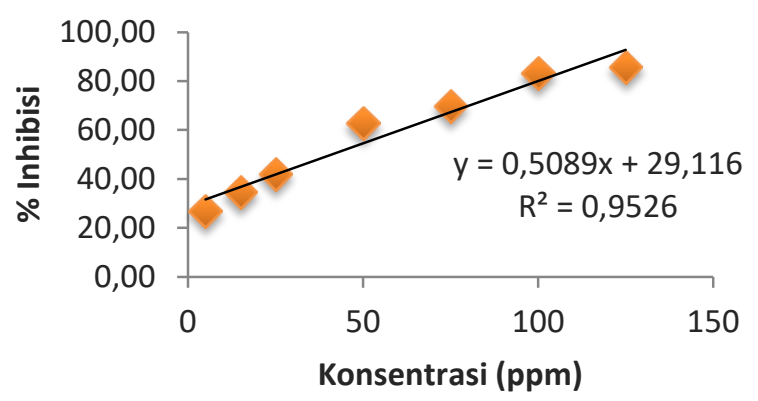

Gambar 1. Kurva regresi linier pengujian aktivitas antioksidan fraksi etanol

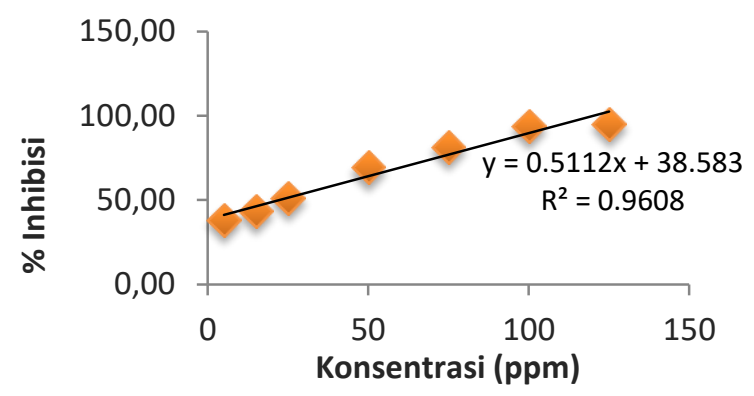

Gambar 2. Kurva regresi linear pengujian aktivitas antioksidan fraksi etil asetat

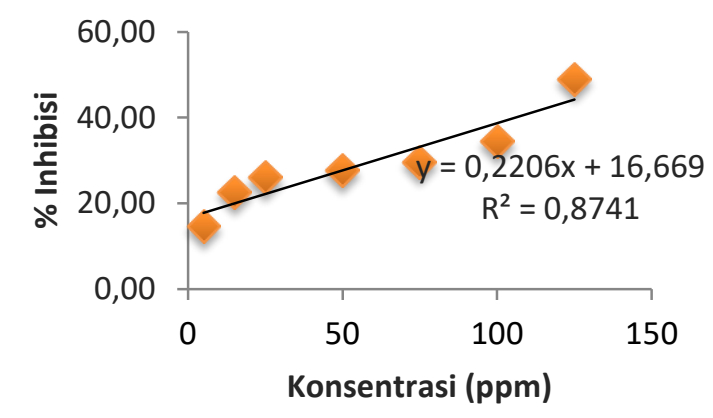

Gambar 3. Kurva regresi linear pengujian aktivitas antioksidan fraksi n-heksana

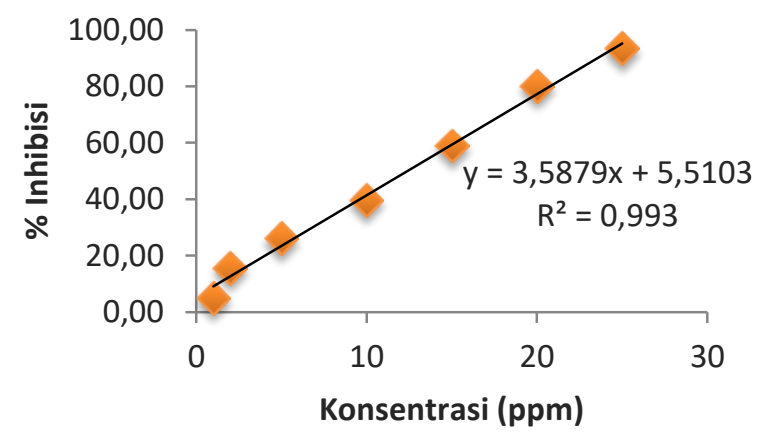

Gambar 4. Kurva regresi linear pengujian aktivitas antioksidan asam askorbat
Berdasarkan 4 kurva regresi linear yang diperoleh keseluruhan memperlihatkan bahwa semakin tinggi konsentrasi sampel maka akan semakin tinggi \% inhibisi. Hal ini dapat dilihat secara kualitatif dengan terjadinya perubahan warna radikal DPPH dari ungu menjadi kuning, yang terjadi karena adanya donor atom hidrogen dari sampel yang mengandung senyawa antioksidan kepada radikal DPPH sehingga tereduksi menjadi bentuk yang lebih stabil yaitu DPPHH (1,1-difenil-2-pikrilhidrazin) [10]. Seperti yang dapat dilihat pada Gambar 5 .

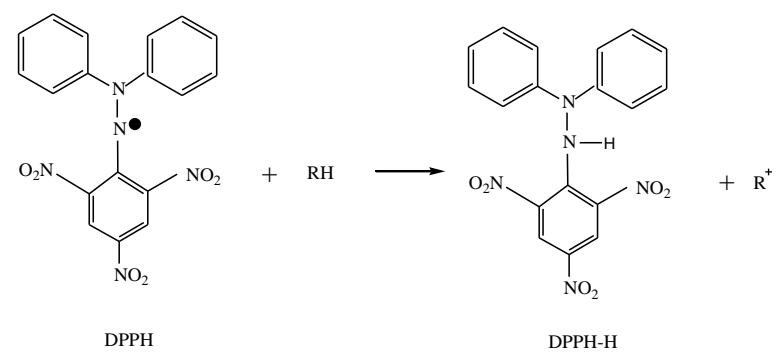

Gambar 5. Reaksi Reduksi DPPH menjadi DPPH-H [9].

Parameter yang umum digunakan untuk mengetahui aktivitas antioksidan adalah dengan menentukan nilai inhibition concentration $50 \%\left(\mathrm{IC}_{50}\right)$. Nilai $\mathrm{IC}_{50}$ dari masing-masing fraksi daun jarak merah dan asam askorbat dapat dilihat pada Tabel 1 .

Tabel 1. Tabel Nilai IC $_{50}$ Ekstak Daun J. gossypifolia L

\begin{tabular}{ccc}
\hline Ekstrak & $\begin{array}{c}\text { Persamaan } \\
\text { Grafik }\end{array}$ & $\begin{array}{c}\text { Nilai } \mathrm{IC}_{50} \\
(\mathrm{ppm})\end{array}$ \\
\hline Fraksi Etanol & $\mathrm{Y}=0,5089 \mathrm{x}+29,116$ & 41,04 \\
$\mathrm{R}^{2}=0,9526$ & \\
\hline $\begin{array}{c}\text { Fraksi Etil } \\
\text { Asetat }\end{array}$ & $\begin{array}{c}\mathrm{y}=0.5113 \mathrm{x}+38.583 \\
\mathrm{R}^{2}=0.9608\end{array}$ & 22,33 \\
\hline Fraksi n- & $\mathrm{Y}=0,2206 \mathrm{x}+16,669$ & 151,09 \\
Heksana & $\mathrm{R}^{2}=0,8741$ & \\
\hline Asam askorbat & $\mathrm{Y}=3,5879 \mathrm{x}+5,5103$ & 12,39 \\
$\mathrm{R}^{2}=0,993$ & \\
\hline
\end{tabular}

Berdasarkan hasil yang didapatkan pada Tabel 1 , menunjukkan bahwa nilai $\mathrm{IC}_{50}$ asam askorbat < fraksi etil asetat < fraksi etanol < fraksi n-heksana, bila semakin kecil nilai $\mathrm{IC}_{50}$ maka aktivitas antioksidan semakin tinggi [11], yang berarti . aktivitas antioksidan asam askorbat > fraksi etil asetat > fraksi etanol > fraksi $n$-heksana. Hal ini diduga karena fraksi etil asetat daun $J$. gossypifolia $L$ masih mengandung berbagai senyawa di dalamnya, yang dapat saling mempengaruhi aktivitas antioksidannya.

Kategori aktivitas antioksidan suatu senyawa dapat digolongkan berdasarkan Tabel 2 : 
Tabel 2. Penggolongan aktivitas antioksidan berdasarkan nilai $\mathrm{IC}_{50}[12]$.

\begin{tabular}{ll}
\hline Nilai $\mathrm{IC}_{50}$ & Kategori \\
\hline$<50 \mathrm{PPM}$ & Sangat Kuat \\
$50 \mathrm{ppm}<\mathrm{IC}_{50}>100 \mathrm{ppm}$ & Kuat \\
$100 \mathrm{ppm}<\mathrm{IC}_{50}>150 \mathrm{ppm}$ & Sedang \\
$150 \mathrm{ppm}<\mathrm{IC}_{50}>200 \mathrm{ppm}$ & Lemah \\
$>200 \mathrm{ppm}$ & Sangat Lemah \\
\hline
\end{tabular}

Fraksi etil asetat dan fraksi etanol daun $J$. gossypifolia $L$ dikategorikan sebagai antioksidan yang sangat kuat dan fraksi n-heksana sebagai antioksidan yang lemah, sehingga fraksi etil asetat dan fraksi etanol yang dipilih untuk uji aktivitas antibakteri terhadap bakteri P. acnes (Tabel 2).

Hasil uji aktivitas anti bakteri dapat dilihat pada Tabel 3 di bawah ini :

Tabel 3. Hasil uji aktivitas antibakteri terhadap P.acnes

\begin{tabular}{ccc}
\hline Sampel & $\begin{array}{c}\text { Konsentrasi } \\
(\mathrm{ppm})\end{array}$ & $\begin{array}{c}\text { Diameter zona } \\
\text { hambat }(\mathrm{mm})\end{array}$ \\
\hline & 62,5 & - \\
Fraksi Etil & 125 & 2 \\
Asetat & 250 & 3 \\
& 500 & 4 \\
& 1000 & 6 \\
\hline Fraksi & 62,5 & - \\
Etanol & 125 & 1 \\
& 250 & 2 \\
& 500 & 5 \\
\hline Kontrol & 1000 & 2 \\
positif & 62,5 & \\
\hline Kontrol & & \\
negatif & - &
\end{tabular}

Dari hasil yang diperoleh diketahui bahwa aktivitas antibakteri terhadap P.acnes menunjukkan fraksi etanol pada konsentrasi 62,5 dan 125 ppm tidak dapat memberikan daya penghambatan terhadap bakteri , begitu juga fraksi etil asetat pada konsentrasi 62,5 ppm tidak dapat memberikan daya penghambatan terhadap bakteri P.acnes. Hal ini terjadi diduga karena rendahnya aktivitas antibakteri senyawa metabolit sekunder yang terkandung pada kedua fraksi tersebut sehingga tidak memberikan daya penghambatan terhadap bakteri P.acnes pada konsetrasi tersebut. Dibandingkan dengan kontrol positif tetrasiklin dengan konsentrasi $62,5 \mathrm{ppm}$ dapat memberikan daya penghambatan terhadap bakteri P.acnes sebesar $2 \mathrm{~mm}$, jadi ekstrak yang dihasilkan pada penelitian ini mempunyai daya hambat yang lebih kecil dari pada kontrol. Aktivitas antibakteri dapat dikategorikan berdasarkan Tabel 4.
Tabel 4. Tingkatan penghambatan pertumbuhan bakteri [13].

\begin{tabular}{ll}
\hline Zona hambat & Kategori \\
\hline$<5 \mathrm{~mm}$ & Lemah \\
$5-10 \mathrm{~mm}$ & Sedang \\
$10-19 \mathrm{~mm}$ & Kuat \\
$20 \mathrm{~mm}$ & Sangat kuat \\
\hline
\end{tabular}

Berdasarkan hasil penelitian diameter zona hambat yang terbentuk terhadap bakteri P.acnes dapat dikategorikan untuk fraksi etil asetat pada konsentrasi 125, 250, dan 500 ppm termasuk dalam kategori lemah sedangkan fraksi etanol pada konsentrasi 250 dan 500 ppm dikategorikan lemah, sedangkan pada konsentrasi $1000 \mathrm{ppm}$ untuk kedua fraksi tersebut dikategorikan sedang dalam menghambat pertumbuhan bakteri P.acnes.

\section{KESIMPULAN}

Aktivitas antioksidan fraksi etanol, etil asetat dan n-heksana ekstrak daun J. gossypifolia L menunjukkan adanya potensi sebagai antioksidan dengan nilai $\mathrm{IC}_{50}$ masing-masing sebesar $41,04 \mathrm{ppm}, 22,33 \mathrm{ppm}$ dan 151,09 ppm.

Daya hambat fraksi etanol dan etil asetat ekstrak daun J.gossypifolia $L$. terhadap pertumbuhan bakteri P.acnes dikategorikan sedang untuk keduanya pada konsentrasi 1000 ppm dengan diameter zona hambat masing-masing sebesar $5 \mathrm{~mm}$ dan $6 \mathrm{~mm}$.

\section{SARAN}

Perlu dilakukan penelitian lebih lanjut terhadap struktur senyawa murni yang paling berperan sebagai antioksidan dan antibakteri dalam daun $J$. gossypifolia L..

\section{DAFTAR PUSTAKA}

[1] Oprica, C., L. Emtetam, J. Lapins, E. Borglund, F. Nyberg, K. Stenlund, L. Lundeberg dan C. E. Nord. 2004. Antibiotic-resistant Propionibact erium acnes on the skin of patients with moderate to severe acne in Stockholm. Anaerobe 10(3):155-164.

[2] Darmawi, Z.H. Manaf dan F. Putranda. 2013. Daya Hambat Getah Jarak Cina (Jatropha multifida L.) Terhadap Staphylococcus aureus Secara In Vitro. Jurnal Medika Veterinaria 7(2):113-115.

[3] Utami, P. . 2008. Buku Pintar Tanaman Obat .Cetakan Pertama. Tanggerang: PT. Agromedia Pustaka. ISBN : 979-006-194-3. 
[4] Aboaba,S.A., M.A. Adebayo, I.A. Orgunwande, T.O.Olayiwola. 2015. Volatile constituents of Jatropha gossypifolia L. grown in Nigeria. American Journal of Essential Oils and Natural Products 2(4):08-11.

[5] Okoh, S. O., B. C. Iweriebor,O. O. Okoh, U. U. Nwodo, A. I. Okoh. 2016. Antibacterial and Antioxidant Properties of the Leaves and Stem Essential Oils of Jatropha gossypifolia L. BioMed Research International. 1-9.

[6] Andriani. Y, 2010, Study Correlation between antioxidant activity and total phenollics content of Phaleria Macrocarpa leaves extract, UMTAS International conference, University Malaysia Terengganu (UMT) Kuala Terengganu Malaysia, 6-8 Mei.

[7] Sayuti, K dan R. Yenrina. 2015. Antioksidan Alami dan Sintetik. Cetakan pertama. Padang : Andalas University Press. ISBN 978-602-8821-97-1

[8] Andriani. Y, 2015, Apotosis property of Hypnophytum formicarum against MCF-7 Cells,International conference on Natural Products (ICNP), Perak Malaysia, 24-25 March.

[9] Tristanto,R., M.A. Putri, A.P. Situmorang dan Suryanti. 2014. Optimalisasi Pemanfaatan Daun Lamun Thalassia hemprichii Sebagai Sumber Antioksidan Alami. Jurnal Saintek Perikanan. 10(1):26-29.
[10] Prakash, A., F. Rigelhof dan E. Miller. 2001. Antioxidant Activity.Medallion Laboratories : Analithycal Progress.19(2):1-4.

[11] Molyneux, P. 2004.The Use Of The Stable Free Radikal Diphenylpicrylhydrazyl (DPPH) For Estimating Antioxidant Activity. Journal Science Of Technology 26 (2): 211219.

[12] Andriani, Y. N.M. Ramli, D.F. Syamsumir, M.N.I. Kassim, J. Jaafar, N.A. Aziz, L. Marlina, N.S. Musa, H. Mohamad,, 2015, Phytochemical Analysis, Antioxidant, Anti bacterial and Cytotoxicity Properties Of Keys and Cores Parts Of Pandanus tectorius Fruits, Arabian Journal of Chemistry.

[13] Andriani. Y, 2016, Anti bacterial , cytotoxiccity and anti-inflammatory activities of Hexane fracttions from Pandanus tectorius keys part, International Conference on Natural Products (ICNP), Surabaya Indonesia, 24-26 Agustus

Penulisan Sitasi Artikel ini ialah :

Pangestu, N,S, Nurhamidah, Elvinawati, 2017, Aktivitas Antioksidan dan Anti Bakteri Ekstrak Daun Jatropha gossypifolia L, Alotrop. 1(1): 15-19. 